\title{
Estimating the volume of Alpine glacial lakes
}

\author{
S. J. Cook $^{1}$ and D. J. Quincey ${ }^{2}$ \\ ${ }^{1}$ School of Science and the Environment, Manchester Metropolitan University, Chester Street, \\ Manchester, M1 5GD, UK \\ ${ }^{2}$ School of Geography, University of Leeds, Leeds, LS2 9JT, UK
}

Correspondence to: S. J. Cook (s.j.cook@mmu.ac.uk) and D. J. Quincey (d.j.quincey@leeds.ac.uk)

Received: 18 August 2015 - Published in Earth Surf. Dynam. Discuss.: 11 September 2015

Revised: 23 November 2015 - Accepted: 27 November 2015 - Published: 14 December 2015

\begin{abstract}
Supraglacial, moraine-dammed and ice-dammed lakes represent a potential glacial lake outburst flood (GLOF) threat to downstream communities in many mountain regions. This has motivated the development of empirical relationships to predict lake volume given a measurement of lake surface area obtained from satellite imagery. Such relationships are based on the notion that lake depth, area and volume scale predictably. We critically evaluate the performance of these existing empirical relationships by examining a global database of glacial lake depths, areas and volumes. Results show that lake area and depth are not always well correlated $\left(r^{2}=0.38\right)$ and that although lake volume and area are well correlated $\left(r^{2}=0.91\right)$, and indeed are auto-correlated, there are distinct outliers in the data set. These outliers represent situations where it may not be appropriate to apply existing empirical relationships to predict lake volume and include growing supraglacial lakes, glaciers that recede into basins with complex overdeepened morphologies or that have been deepened by intense erosion and lakes formed where glaciers advance across and block a main trunk valley. We use the compiled data set to develop a conceptual model of how the volumes of supraglacial ponds and lakes, moraine-dammed lakes and ice-dammed lakes should be expected to evolve with increasing area. Although a large amount of bathymetric data exist for moraine-dammed and ice-dammed lakes, we suggest that further measurements of growing supraglacial ponds and lakes are needed to better understand their development.
\end{abstract}

\section{Introduction}

Globally, there is a general trend of mountain glacier recession and thinning in response to climatically controlled negative mass balances (Zemp et al., 2015). In most mountain ranges, glacier shrinkage since the Little Ice Age has been accompanied by the development of proglacial, ice-marginal and supraglacial lakes impounded by moraine and outwash fan head structures (e.g. Röhl, 2008; Janský et al., 2009; Thompson et al., 2012; Carrivick and Tweed, 2013; Westoby et al., 2014). The integrity of these structures often reduces over time as ice cores degrade and slopes are subject to mass wasting processes, raising the concern of dam failure. Further, the location of these lakes in valleys with steep, unstable slopes, often in tectonically active regions prone to earthquakes, means that rock and ice avalanches are common, adding a further threat of displacement-wave overtopping if avalanche material were to impact the lake (e.g. Schneider et al., 2014). Dam failure, breach or overtopping can lead to glacial lake outburst floods (GLOFs) that pose a significant threat to lives, industry and infrastructure (Richardson and Reynolds, 2000; Westoby et al., 2014). Other potentially dangerous lakes are dammed by ice, either in ice-marginal locations where surface meltwater or water from tributary valleys ponds against the glacier margin (e.g. Merzbacher Lake - Mayer et al., 2008; Lac de Rochemelon - Vincent et al., 2010) or where advancing (often surging) glaciers block river drainage (e.g. Kyagar Glacier - Haemmig et al., 2014). In these situations, water may escape through subglacial tunnels, along the ice margin between the glacier and valley side or by mechanical failure of the ice dam (Walder and Costa, 1996; Clague and Evans, 2000).

Crucial to the management of GLOF hazards is the ability to assess the likelihood and magnitude of any such event. 
In most cases, this requires an understanding of the volume of water impounded in the lake, the structural integrity and longevity of the dam, potential external trigger mechanisms and the likely flow path of the flood (e.g. Richardson and Reynolds, 2000; McKillop and Clague, 2007; Westoby et al., 2014). There are a number of challenges for anyone interested in estimating or calculating lake volume. Field studies are complicated by the fact that many glacial lakes are located in relatively inaccessible or physically challenging and dangerous environments, making bathymetric surveys of lake basins difficult. As yet, there is no reliable technique available for measuring lake bathymetry or volume from satellite imagery where turbidity precludes the derivation of reflectance-depth relationships (e.g. Box and Ski, 2007). Consequently, a number of studies have adopted an empirical approach to volume calculation from satellite imagery based on known relationships between lake depths, areas and volumes (e.g. Evans, 1986; O'Connor et al., 2001; Huggel et al., 2002; Yao et al., 2012; Loriaux and Cassassa, 2013; Carrivick and Quincey, 2014). This allows rapid and simple calculation of lake volumes from widely available satellite imagery, whilst avoiding the necessity for often challenging fieldwork.

Two key empirical approaches have become adopted for lake volume estimation. First, O'Connor et al. (2001) derived a relationship between lake area and volume for morainedammed lakes of the Central Oregon Cascade Range. Lake volumes were derived from detailed bathymetric surveys. The relationship takes the form

$V=3.114 A+0.0001685 A^{2}$,

where $V$ is lake volume (in $\mathrm{m}^{3}$ ) and $A$ is the surface area of the lake (in $\mathrm{m}^{2}$ ). This relationship has been applied, for example, to assist in the prediction of GLOF hazards in British Columbia by McKillop and Clague (2007).

An alternative relationship was derived by Huggel et al. (2002). First, Huggel et al. demonstrated that lake depth and area were correlated for a combination of ice-dammed, moraine-dammed and thermokarst lakes at a number of locations globally. This relationship takes the form

$D=0.104 A^{0.42}$

where D is the mean lake depth (in metres), and area is measured in square metres. Hence, Huggel et al. (2002) derived a relationship for volume (in $\mathrm{m}^{3}$ ) with the form

$V=0.104 A^{1.42}$.

As the authors point out, this relationship has much in common with that of the Canadian Inland Water Directorate, cited in Evans (1986), which is based on ice-dammed lakes and takes the form

$V=0.035 A^{1.5}$.
The relationship of Huggel et al. (2002) has gained significant appeal and has been applied directly in several studies to estimate lake volume (e.g. Huggel et al., 2004; Bolch et al., 2011; Mergili and Schneider, 2011; Jain et al., 2012; Gruber and Mergili, 2013; Wilcox et al., 2013; Byers et al., 2013; Che et al., 2014) or has been modified for specific locations (e.g. Loriaux and Cassassa, 2013; Yao et al., 2012). Importantly, however, there has been no systematic assessment of whether these empirical relationships can be applied confidently across a range of locations and contexts (e.g. ice-dammed, moraine-dammed, supraglacial). Further, the relationships presented in Eqs. (1), (3) and (4) are based on the assumption that lake area and volume should scale predictably. However, glaciers are known to erode basins with complex morphometries, meaning that associated lakes may have complex bathymetries and hence more unpredictable depth-area-volume relationships (e.g. Cook and Swift, 2012). Likewise, lake depths and hypsometries may be determined on a local scale by sedimentation or, where a lake develops supraglacially, by the underlying ice and debris surface. Empirical volume-area relationships can also give a misleading impression of the predictability of lake volumes because lake volume is dependent on area (Wang et al., 2012; Haeberli, 2015). Hence, higher degrees of correlation between lake area and volume often mask the complexity of lake basin morphometry. In this study, we test the extent to which lake depth, area and volume are correlated under a range of scenarios based on a compilation of published data sets of lake basin morphometries. In particular, we examine the error between published lake volume estimates based on interpolation from bathymetric measurements compared to volumes calculated by using the empirical relationships of O'Connor et al. (2001), Evans (1986) and Huggel et al. (2002).

\section{Data and Methods}

We have compiled a data set of glacial lake areas, average depths and bathymetrically derived volumes from published articles and reports (Tables S1 and S2 in the Supplement). The data set comprises 42 lakes with measured lake areas and mean depths (Table S1), most of which (36) were reported in the publications themselves. The remainder were derived by the current authors from published bathymetric maps, which were georeferenced in ArcMap and then digitised; mean depth measurements were then interpolated from the contour data. Some of these data represent duplicate readings from individual sites where repeat measurements have been made over several years. When these duplicates are removed, the data set comprises 30 lakes (Table 1). Lake area and depth data presented in Huggel et al. (2002) represent a further 15 data points, and we derive empirical relationships between lake area and depth with and without duplicates and with and without the data of Huggel et al. (2002) 
Table 1. Summary of relationships derived from measured lake area and depth data.

\begin{tabular}{|c|c|c|c|c|c|c|}
\hline Relationship & $\begin{array}{l}\text { Number of } \\
\text { data points (n) }\end{array}$ & $r^{2}$ value & Range in area $\left(\mathrm{m}^{2}\right)$ & $\begin{array}{l}\text { Range in } \\
\text { depth (m) }\end{array}$ & $\begin{array}{l}\text { Depth }(\mathrm{m}) \text { vs. area } \\
\left(\mathrm{m}^{2}\right) \text { relationship }\end{array}$ & $\begin{array}{l}\text { Volume }\left(\mathrm{m}^{3}\right) \text { vs. area } \\
\left(\mathrm{m}^{2}\right) \text { relationship }\end{array}$ \\
\hline $\begin{array}{l}\text { Re-plot of Huggel et } \\
\text { al. (2002) data }\end{array}$ & 15 & 0.95 & $3500-6 \times 10^{6}$ & $2.9-83.3$ & $D=0.1217 A^{0.4129}$ & $V=0.1217 A^{1.4129}$ \\
\hline $\begin{array}{l}\text { Compilation of data in this } \\
\text { study including duplicate } \\
\text { sites }\end{array}$ & 42 & 0.38 & $35900-172 \times 10^{6}$ & $6.2-150.1$ & $D=0.5057 A^{0.2884}$ & $V=0.5057 A^{1.2884}$ \\
\hline $\begin{array}{l}\text { Compilation of data in this } \\
\text { site excluding duplicate } \\
\text { sites }\end{array}$ & 30 & 0.60 & $35900-172 \times 10^{6}$ & $6.2-150.1$ & $D=0.1746 A^{0.3725}$ & $V=0.1746 A^{1.3725}$ \\
\hline $\begin{array}{l}\text { Compilation of data in } \\
\text { this study including dupli- } \\
\text { cate sites plus Huggel } \\
\text { et al. (2002) data }\end{array}$ & 57 & 0.57 & $3500-172 \times 10^{6}$ & $2.9-150.1$ & $D=0.3211 A^{0.324}$ & $V=0.3211 A^{1.324}$ \\
\hline $\begin{array}{l}\text { Compilation of data in } \\
\text { this study excluding dupli- } \\
\text { cate sites plus } \\
\text { Huggel et al. (2002) data }\end{array}$ & 45 & 0.74 & $3500-172 \times 10^{6}$ & $2.9-150.1$ & $D=0.1697 A^{0.3778}$ & $V=0.1697 A^{1.3778}$ \\
\hline
\end{tabular}

included (Table 1). Empirical relationships are derived by fitting power-law functions to the area-depth data plotted on logarithmic scales. We have not used depth data derived from dividing bathymetrically derived volumes over measured areas to avoid the issue of auto-correlation.

There are 69 lakes with measured areas and volumes calculated from bathymetric data (Table 2). As with the areadepth data, most of these data points (63) were reported directly in the literature; the remainder were derived from interpolated bathymetric map data by the current authors. Removal of duplicate sites reduces the number of data points to 49. The area and volume data of O'Connor et al. (2001) represent a further six sites and, again, empirical relationships are derived with and without the duplicate sites and data from O'Connor et al. (2001) by fitting a power-law function to the data.

Derivation of power-law functions for area-depth and area-volume data is performed in conjunction with a calculation of the coefficient of determination, $r^{2}$. The data set includes some sites where lake depths, areas and volumes have been measured or estimated at different times. We present relationships in Table 1 that both include these duplicate data points, and exclude them where only the most recent measurement or estimate is included. Hence, we account for the influence of duplicate data points skewing the data set. Other studies (e.g. Loriaux and Casassa, 2013) have included duplicates to derive their area-depth and area-volume relationships. Likewise, we include relationships derived purely from Huggel et al. (2002) data or from our compiled data, and from combinations of these data sets. This allows comparison between our data and those of Huggel et al. (2002), whilst also acknowledging that these data sets could reason- ably be combined. Since our data are sourced from other studies, we do not account for seasonal variations (e.g. melt season vs. winter) in water depth, area and volume, but we acknowledge that this could influence these measurements to some extent.

High $r^{2}$ values lend support to the possibility of a relationship between two variables, but outliers can exist in data sets even where the $r^{2}$ value is high. Hence, in order to investigate the extent to which existing empirical relationships (Eqs. 1, 3 and 4) are able to estimate accurately the volume of individual lakes, we provide a quantification of error. Huggel et al. (2004) calculated error (\%) as the difference between "measured" and calculated volumes divided by the calculated volume, whereas Allen et al. (2009) calculated error $(\%)$ as the difference between "measured" and calculated volumes, divided by the "measured" volume. It should be noted that lake volumes cannot truly be measured because they involve some degree of interpolation from bathymetric measurements (Haeberli, 2015). We adopt the approach of Huggel et al. (2004) in dividing by calculated volume, because the method of Allen et al. (2009) generates varying error values depending on whether the bathymetrically derived (i.e. "measured") lake volume is less than or greater than the calculated volume.

\section{Results}

\subsection{Lake area vs. depth}

Figure 1 presents all of the lake area against measured mean depth data from Huggel et al. (2002) and from the range of data compiled in this study, with best-fit line equations and $r^{2}$ values shown for both. O'Connor et al. (2001) derived 
Table 2. Summary of relationships derived from measured lake area and bathymetrically derived volume data.

\begin{tabular}{|c|c|c|c|c|c|}
\hline Relationship & $\begin{array}{l}\text { Number of } \\
\text { data points (n) }\end{array}$ & $r^{2}$ value & Range in area $\left(\mathrm{m}^{2}\right)$ & $\begin{array}{l}\text { Range in } \\
\text { volume }\left(\times 10^{6} \mathrm{~m}^{3}\right)\end{array}$ & $\begin{array}{l}\text { Volume }\left(\mathrm{m}^{3} \times 10^{6}\right) \text { vs. } \\
\text { area }\left(\mathrm{m}^{2}\right) \text { relationship }\end{array}$ \\
\hline $\begin{array}{l}\text { Re-plot of O'Connor et } \\
\text { al. (2001) }\end{array}$ & 6 & 0.97 & $6120-70000$ & $0.027-0.9$ & $V=3 \times 10^{-7} A^{1.3315}$ \\
\hline $\begin{array}{l}\text { Compilation of data in this } \\
\text { study including duplicate } \\
\text { sites }\end{array}$ & 69 & 0.91 & $28000-19.5 \times 10^{6}$ & $0.143-2454.6$ & $V=2 \times 10^{-7} A^{1.3719}$ \\
\hline $\begin{array}{l}\text { Compilation of data in this } \\
\text { study excluding duplicate } \\
\text { sites }\end{array}$ & 49 & 0.94 & $40000-19.5 \times 10^{6}$ & $0.2-2454.6$ & $V=7 \times 10^{-8} A^{1.4546}$ \\
\hline $\begin{array}{l}\text { Compilation of data in this } \\
\text { study including duplicate } \\
\text { sites plus O'Connor et } \\
\text { al. (2001) data }\end{array}$ & 75 & 0.94 & $6120-19.5 \times 10^{6}$ & $0.027-2454.6$ & $V=2 \times 10^{-7} A^{1.3721}$ \\
\hline $\begin{array}{l}\text { Compilation of data in this } \\
\text { study excluding duplicate } \\
\text { sites plus O'Connor et } \\
\text { al. (2001) data }\end{array}$ & 55 & 0.96 & $6120-19.5 \times 10^{6}$ & $0.027-2454.6$ & $V=1 \times 10^{-7} A^{1.434}$ \\
\hline
\end{tabular}

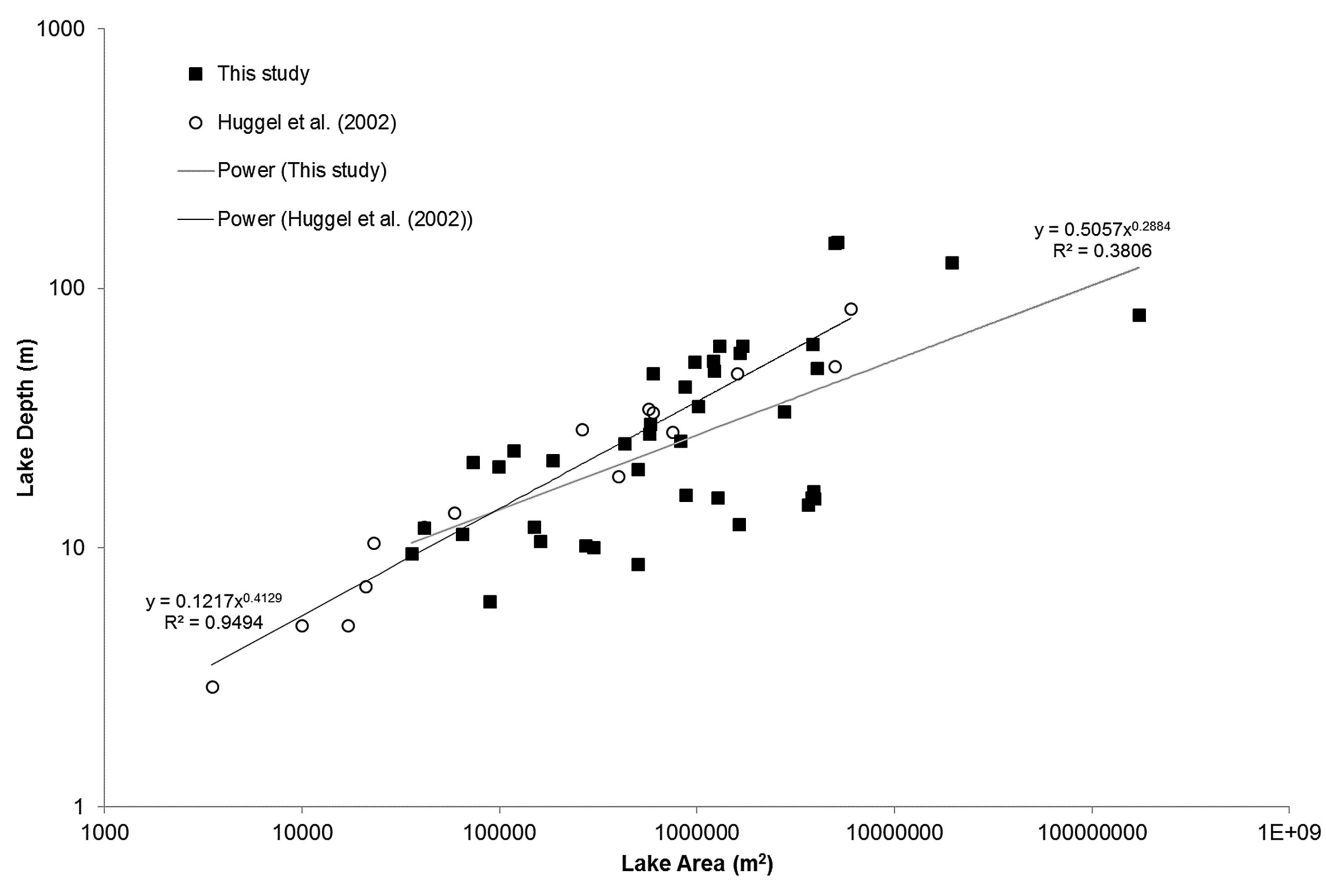

Figure 1. Plot of lake area vs. depth for the data compiled in this study (including duplicate measurements of individual lakes) and the data presented by Huggel et al. (2002). Best-fit lines and corresponding equations and $r^{2}$ values are presented for both data sets. 


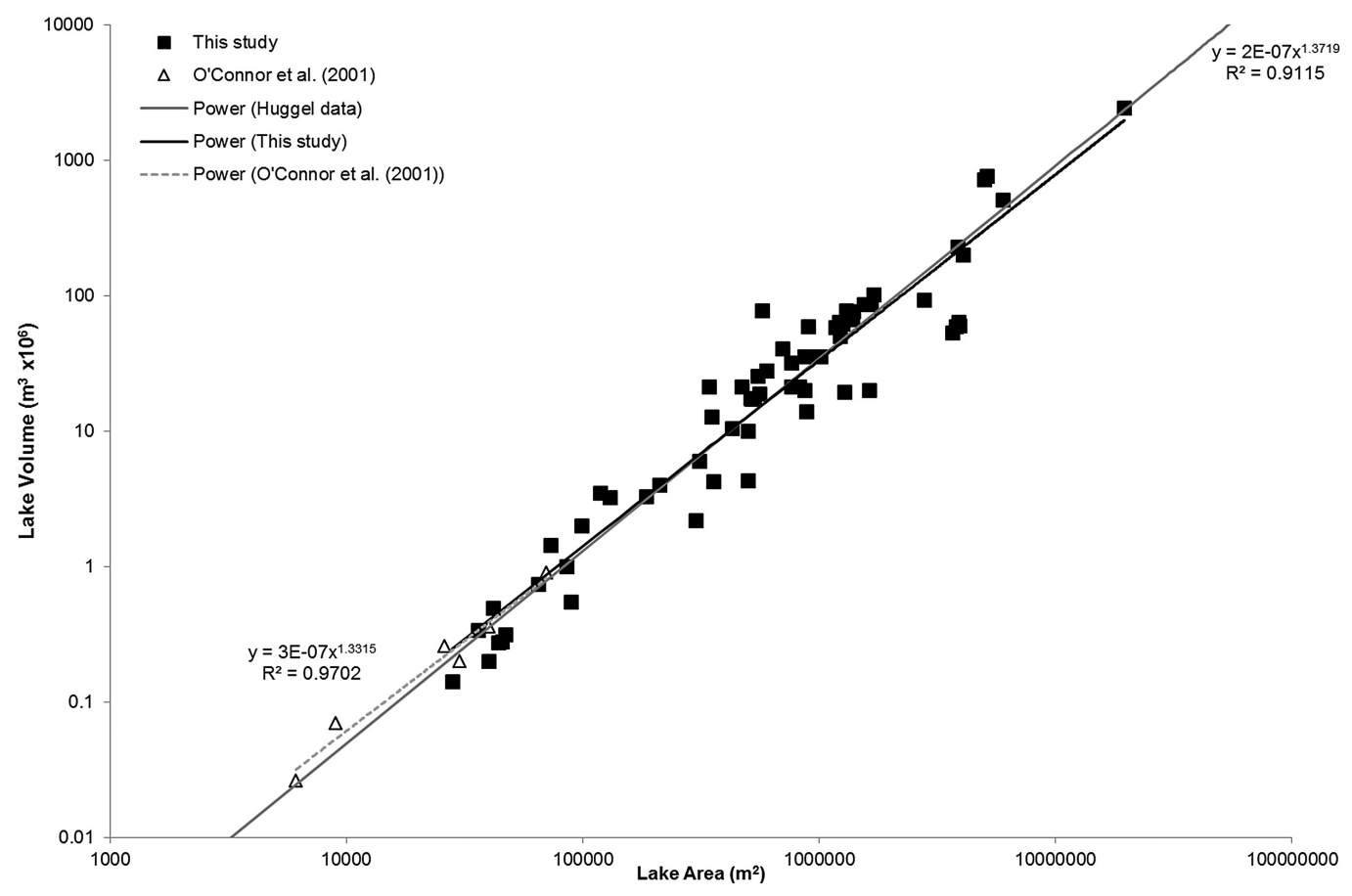

Figure 2. Plot of lake area against volume for the data compiled in this study and for the data presented by O'Connor et al. (2001). Best-fit lines and corresponding equations and $r^{2}$ values are presented for both data sets. The solid grey line represents the area-volume relationship of Huggel et al. (2002) (Eq. 3) for reference.

their area-volume relationship (Eq. 1) from a plot of area vs. volume (their Fig. 18), meaning that no depth data are available to plot on Fig. 1 from their study. Table 1 presents a summary of the resulting depth-area relationships and the volume-area relationships, the latter having been derived following Huggel et al. (2002) (i.e. the transition from Eqs. 2 to 3$)$.

The re-plot of data presented in Huggel et al. (2002) differs from that presented in their study (their Fig. 1). Indeed, the one significant outlier in their graph actually plots very close to the best-fit line for their data, and two points that appear in their Table 2 do not appear in their Fig. 1. Hence, overall, the $r^{2}$ value for the data presented in Huggel et al. (2002) increases to 0.95 (from 0.91 as stated in their study), and the best-fit line equation, $D=0.1217 A^{0.4129}$, differs slightly from Eq. (2) (Table 1). Accordingly, Eq. (3) for lake volume becomes $V=0.1217 A^{1.4129}$. We note, however, that Huggel et al. (2002) also employed a bias correction procedure in their study, although this was not described.

Plotting all available data compiled in this study (including duplicate readings for some sites where there are data for two or more measurement periods) reveals a low $r^{2}$ value of 0.38 , demonstrating that there is significant variability in lake depth for any given area. For example, Fig. 1 illustrates that a lake with an area of between $\sim 4000000$ and $5000000 \mathrm{~m}^{2}$ could have a mean depth of between $\sim 15$ and $150 \mathrm{~m}$. Further, there are many visually obvious outliers in the data set presented in Fig. 1 that deviate greatly from the best-fit line of Huggel et al. (2002). If duplicate sites are removed (leaving only the most recently measured lake areas and depths), the $r^{2}$ value increases to 0.60 because the influence of individual lakes is reduced.

Since the data of Huggel et al. (2002) plot with a high $r^{2}$ value, their combination with our data, both where duplicates are included or excluded, increases the $r^{2}$ value for best-fit lines to 0.57 and 0.74 respectively (Table 1). Overall, our combined data demonstrate significant variability in the relationship between lake area and depth and hence between area and volume.

\subsection{Lake area vs. volume}

O'Connor et al. (2001) derived their lake area-volume relationship (Eq. 1) directly from measured lake areas and lake volumes derived from measured bathymetries. Figure 2 presents lake area against volume for the data compiled in this study and in O'Connor et al. (2001). For reference, a line representing the lake volumes predicted by using the Huggel et al. (2002) relationship (Eq. 3) is also plotted in Fig. 2. Table 2 presents a summary of these relationships, as well as combinations of these data sets with and without the inclusion of duplicate data points from individual lakes.

A re-plot of the O'Connor et al. (2001) data reveals a high $r^{2}$ value of 0.97 (Fig. 2, Table 2), indicating a strong depen- 
dence of lake volume on area. Figure 2 demonstrates that there is also a strong relationship between lake area and volume for the data compiled in this study, with a high $r^{2}$ value of 0.91. Both the data of O'Connor et al. (2001) and in this study plot in close association with the best-fit line representing the lake area-volume relationship of Huggel et al. (2002). The $r^{2}$ value increases once duplicate lake data points are removed, largely because of outliers in the data set that also happen to be duplicate data points (Table 2).

Despite the visually close association of most of the data points in Fig. 2 and the relatively high $r^{2}$ values shown in Table 2, there are a number of outliers in the data set that become more apparent when the upper and lower ends of the data set are curtailed (essentially, zooming-in on the mid-range of the data set). For example, at a lake area of $\sim 300000 \mathrm{~m}^{2}$, the corresponding lake volume could be as little as 2.2 million $\mathrm{m}^{3}$ or as much as 21.3 million $\mathrm{m}^{3}$. Likewise, at $\sim 500,000 \mathrm{~m}^{2}$ the volume could be between $\sim 10$ and 77.3 million $\mathrm{m}^{3}$, and at $\sim 4$ to 5 million $\mathrm{m}^{2}$ the volume could be between $\sim 53$ and $\sim 770$ million $\mathrm{m}^{3}$. Hence, there can be order-of-magnitude differences in volume for a given lake area.

\subsection{Error between modelled and bathymetrically derived lake volume}

Table 3 presents a measure of error between bathymetrically derived volumes and the volumes calculated using Eqs. (1), (3) and (4). To identify lakes whose volumes are not well predicted by Eqs. (1), (3) and (4), we categorise the calculated errors such that an error between bathymetrically derived and modelled volumes of $\pm 25-49 \%$ is considered to represent a lake with a "moderately unpredictable" volume (highlighted yellow), an error of $\pm 50-99 \%$ is considered to be a lake with "unpredictable" volume (highlighted orange), and an error of beyond $\pm 100 \%$ is considered to represent a lake with "highly unpredictable" volume (highlighted red).

Table 3 demonstrates that the use of O'Connor et al.'s (2001) volume calculation leads to very large errors in most cases. The relationships of Huggel et al. (2002) and Evans (1986) perform better in general, although there are exceptions. For ease of interpretation, we ascribe error scores in the right-hand columns. For any individual estimate, errors beyond $\pm 100 \%$ are scored 3, errors between \pm 50 and $99 \%$ are scored 2, errors between \pm 25 and $49 \%$ are scored 1 and errors of $\pm 0-24 \%$ are scored 0 . The first of the right-hand columns is the sum of these scores from all three methods of volume estimation. A combined score of 7-9 is considered "highly unpredictable", a score of 4-6 is considered "unpredictable" and a score of $0-3$ is considered to be "reasonably predictable".

Since the method of O'Connor et al. (2001) seems to overestimate greatly lake volumes in most cases, even when the other methods are reasonable predictors, the furthest righthand column presents error scores based only on Huggel et al. (2002) and Evans (1986). Combined scores of 5-6 are considered "highly unpredictable", and scores of 3-4 are considered "unpredictable". Scores of 0-2 are considered to be "reasonably predictable". The results of these two righthand columns are broadly comparable, identifying the same lakes in most cases.

Table 3 reveals several lakes with "highly unpredictable" lake volumes including Hooker, Ivory Lake, Laguna Safuna Alta, Lake No Lake, Nef and Ngozumpa 4. A group with 'unpredictable' volumes includes Checquiacocha, Gelhaipuco, Hazard/Steele Lake, Imja (in 1992), Maud Lake, Mt Elbrus, Mueller, Ngozumpa, Petrov, Quitacocha and Tam Pokhari.

The relationship of O'Connor et al. (2001) outperforms those of Huggel et al. (2002) and/or Evans (1986) in a few cases including, including many of the "highly unpredictable" lake volumes. Specifically, these are Hooker, Imja (in 1992), Ivory, Laguna Safuna Alta, Lake No Lake, Miage, MT Lake, Ngozumpa 4, Quitacocha and Tam Pokhari.

\section{Discussion}

\subsection{Performance of existing relationships}

We have compiled a data set of Alpine glacial lake areas, depths and volumes in order to evaluate critically the use of existing empirical relationships for the estimation of glacial lake volumes. The plot of lake area against mean lake depth (Fig. 1) reveals a significant degree of scatter, indicating that lake area and depth do not always scale predictably. Hence, empirical relationships for estimating lake volume that are founded upon a strong correlation between lake area and depth (e.g. that of Huggel et al., 2002) should be used with caution. Equally, Fig. 2 shows that there are also significant outliers in the data set of measured areas against bathymetrically derived volumes, even though one might expect some degree of auto-correlation between area and volume (Huggel et al., 2002; Mergili and Schneider, 2011).

In general, the empirical relationships derived by Evans (1986) and Huggel et al. (2002) perform better at estimating lake volumes than the relationship of O'Connor et al. (2001) (Table 3). These relationships are also more robust because they are derived from a relationship between lake depth and area and hence are not affected by auto-correlation (Huggel et al., 2002; Mergili and Schneider, 2011). The replotting of lake depth and area data from Huggel et al. (2002) reveals a slightly different relationship to that reported in the original study (Table 1), although it will make little difference to calculated volumes if either the original or revised relationship is used. As McKillop and Clague (2007) explain, the O'Connor et al. (2001) relationship is derived from a data set of lakes whose volumes are large for their relatively small areas. This is a consequence of moraine dam emplacement on steep slopes, giving comparatively large depths and volumes. Hence, the relationship of O'Connor et al. (2001) should be expected to overestimate lake volume with increasing lake 
Table 3. Comparison of bathymetrically derived lake volumes with those calculated using existing empirical relationships. Errors are calculated according to Huggel et al. (2004) and coded such that the error between bathymetrically derived and modelled volumes of $\pm 25-49 \%$ is considered "moderately unpredictable" volume (italic), the error $\pm 50-99 \%$ is considered "unpredictable" (bold) and an error of beyond $\pm 100 \%$ is considered "highly unpredictable" (bold-italic). Error scores are provided in the right-hand columns for ease of interpretation. Errors beyond $\pm 100 \%$ are scored 3, errors between \pm 50 and $99 \%$ are scored 2, errors between \pm 25 and $49 \%$ are scored 1 and errors of $\pm 0-24 \%$ are scored 0 . The first of the right-hand columns is the sum of these scores from all three methods of volume estimation, and the furthest right-hand column is the sum of scores from the models of Huggel et al. (2002) and Evans (1986).

\begin{tabular}{|c|c|c|c|c|c|c|c|c|c|}
\hline $\begin{array}{l}\text { Site, survey date, } \\
\text { reference(s) }\end{array}$ & $\begin{array}{r}\text { Bathymetrically } \\
\text { derived volume } \\
\qquad\left(\times 10^{6} \mathrm{~m}^{3}\right)\end{array}$ & $\begin{array}{r}\text { Huggel } \\
\text { et al. } \\
(2002) \\
\text { volume }\end{array}$ & $\begin{array}{r}\text { Evans } \\
\text { et al. } \\
(1986) \\
\text { volume }\end{array}$ & $\begin{array}{r}\text { O'Connor } \\
\text { et al. } \\
(2001) \\
\text { volume }\end{array}$ & $\begin{array}{r}\text { Huggel } \\
\text { et al. } \\
(2002) \\
\text { error } \\
(\%)\end{array}$ & $\begin{array}{r}\text { Evans } \\
\text { et al. } \\
(1986) \\
\text { error } \\
(\%)\end{array}$ & $\begin{array}{r}\text { O'Connor } \\
\text { et al. } \\
(2001) \\
\text { error } \\
(\%)\end{array}$ & $\begin{array}{r}\text { Error score } \\
\text { based on all } \\
\text { three volume } \\
\text { estimate } \\
\text { methods }\end{array}$ & $\begin{array}{r}\text { Error score } \\
\text { based on } \\
\text { Huggel et al. } \\
\text { (2002) and } \\
\text { Evans (1986) }\end{array}$ \\
\hline $\begin{array}{l}\text { Abmachimai Co, } \\
\text { Tibet, 1987; } \\
\text { Sakai (2012) }\end{array}$ & 19.0 & 15.1 & 14.7 & 54.6 & 25.7 & 29.5 & -65.2 & 4 & 2 \\
\hline $\begin{array}{l}\text { Ape Lake, } \\
\text { 1984-1985; } \\
\text { Gilbert and } \\
\text { Desloges (1987) }\end{array}$ & 92.8 & 146.4 & 161.4 & 1302.1 & -36.6 & -42.5 & -92.9 & 4 & 2 \\
\hline $\begin{array}{l}\text { Bashkara, 2008; } \\
\text { Petrakov et } \\
\text { al. (2012) }\end{array}$ & 1.0 & 1.0 & 0.9 & 1.5 & -3.8 & 15.3 & -32.5 & 1 & 0 \\
\hline $\begin{array}{l}\text { Briksdalsbreen, } \\
\text { 1979; Duck and } \\
\text { McManus (1985) }\end{array}$ & 0.3 & 0.4 & 0.3 & 0.5 & -30.1 & -12.2 & -39.7 & 2 & 1 \\
\hline $\begin{array}{l}\text { Briksdalsbreen, } \\
\text { 1982; Duck and } \\
\text { McManus (1985) }\end{array}$ & 0.3 & 0.4 & 0.4 & 0.5 & -33.7 & -16.4 & -42.1 & 1 & 0 \\
\hline $\begin{array}{l}\text { Cachet II, } \\
\text { 2008-2009; } \\
\text { Casassa et } \\
\text { al. (2010) }\end{array}$ & 200.0 & 250.5 & 284.7 & 2769.6 & -20.2 & -29.8 & -92.8 & 3 & 1 \\
\hline $\begin{array}{l}\text { Chamlang south, } \\
\text { Nepal, 2009; } \\
\text { Sawagaki et } \\
\text { al. (2012) }\end{array}$ & 35.6 & 28.3 & 28.4 & 130.2 & 26.0 & 25.3 & -72.7 & 4 & 2 \\
\hline $\begin{array}{l}\text { Checquiacocha, } \\
\text { 2008; Emmer and } \\
\text { Vilimek (2013) }\end{array}$ & 12.9 & 7.8 & 7.3 & 21.9 & 64.7 & 76.2 & -41.4 & 6 & 4 \\
\hline $\begin{array}{l}\text { Dig Tsho, Nepal, } \\
\text { pre-2001; ICIMOD } \\
(2001)\end{array}$ & 10.0 & 12.9 & 12.4 & 43.7 & -22.3 & -19.2 & -77.1 & 2 & 0 \\
\hline $\begin{array}{l}\text { Gelhaipuco, 1964; } \\
\text { ICIMOD (2001) }\end{array}$ & 25.5 & 14.7 & 14.2 & 52.3 & 73.6 & 79.2 & -51.3 & 6 & 4 \\
\hline $\begin{array}{l}\text { Goddard, 1994; } \\
\text { Clague and Evans } \\
\text { (1997) }\end{array}$ & 4.0 & 3.8 & 3.4 & 8.1 & 6.5 & 18.8 & -50.5 & 2 & 0 \\
\hline $\begin{array}{l}\text { Godley, 1994; } \\
\text { Warren and } \\
\text { Kirkbride (1998) }\end{array}$ & 102.0 & 73.2 & 77.6 & 492.3 & 22.2 & 15.6 & -81.5 & 2 & 0 \\
\hline $\begin{array}{l}\text { Godley, 1994; } \\
\text { Allen et al. (2009) }\end{array}$ & 85.7 & 70.1 & 74.2 & 463.9 & 39.4 & 31.5 & -79.3 & 4 & 2 \\
\hline
\end{tabular}


Table 3. Continued.

\begin{tabular}{|c|c|c|c|c|c|c|c|c|c|}
\hline $\begin{array}{l}\text { Site, survey date, } \\
\text { reference(s) }\end{array}$ & $\begin{array}{r}\text { Bathymetrically } \\
\text { derived volume } \\
\qquad\left(\times 10^{6} \mathrm{~m}^{3}\right)\end{array}$ & $\begin{array}{r}\text { Huggel } \\
\text { et al. } \\
(2002) \\
\text { volume }\end{array}$ & $\begin{array}{r}\text { Evans } \\
\text { et al. } \\
(1986) \\
\text { volume }\end{array}$ & $\begin{array}{r}\text { O'Connor } \\
\text { et al. } \\
(2001) \\
\text { volume }\end{array}$ & $\begin{array}{r}\text { Huggel } \\
\text { et al. } \\
(2002) \\
\text { error } \\
(\%)\end{array}$ & $\begin{array}{r}\text { Evans } \\
\text { et al. } \\
(1986) \\
\text { error } \\
(\%)\end{array}$ & $\begin{array}{r}\text { O'Connor } \\
\text { et al. } \\
(2001) \\
\text { error } \\
(\%)\end{array}$ & $\begin{array}{r}\text { Error score } \\
\text { based on all } \\
\text { three volume } \\
\text { estimate } \\
\text { methods }\end{array}$ & $\begin{array}{r}\text { Error score } \\
\text { based on } \\
\text { Huggel et al. } \\
\text { (2002) and } \\
\text { Evans (1986) }\end{array}$ \\
\hline $\begin{array}{l}\text { Hazard/Steele, } \\
\text { 1974; Collins } \\
\text { and Clarke (1977) }\end{array}$ & 14.0 & 28.7 & 28.9 & 133.2 & -51.3 & -51.5 & -89.5 & 6 & 4 \\
\hline $\begin{array}{l}\text { Hazard/Steele, } \\
\text { 1979; Clarke } \\
(1982)\end{array}$ & 19.6 & 48.6 & 50.3 & 277.5 & -59.6 & -61.0 & -92.9 & 6 & 4 \\
\hline $\begin{array}{l}\text { Hidden Creek } \\
\text { Lake, 1999-2000; } \\
\text { Cunico (2003) }\end{array}$ & 21.2 & 26.1 & 26.1 & 116.6 & -18.6 & -18.7 & -81.8 & 2 & 0 \\
\hline $\begin{array}{l}\text { Hooker, 1995; } \\
\text { Allen et al. (2009) }\end{array}$ & 41.0 & 20.8 & 20.5 & 84.7 & 97.6 & 100.0 & -51.6 & 7 & 5 \\
\hline $\begin{array}{l}\text { Hooker, 2002; } \\
\text { Allen et al. (2009) }\end{array}$ & 59.0 & 29.7 & 29.9 & 139.3 & 99.0 & 97.4 & -57.6 & 6 & 4 \\
\hline $\begin{array}{l}\text { Hooker, 2009; } \\
\text { Robertson et } \\
\text { al. (2013) }\end{array}$ & 50.0 & 45.7 & 47.2 & 254.6 & 9.5 & 6.0 & -80.4 & 2 & 0 \\
\hline $\begin{array}{l}\text { Imja, Nepal, 1992; } \\
\text { Sakai (2012) }\end{array}$ & 28.0 & 16.7 & 16.3 & 62.5 & 67.9 & 72.1 & -55.2 & 6 & 4 \\
\hline $\begin{array}{l}\text { Imja, Nepal, 2002; } \\
\text { Sakai et al. (2012) }\end{array}$ & 35.8 & 28.0 & 28.1 & 128.5 & 27.9 & 27.4 & -72.1 & 4 & 2 \\
\hline $\begin{array}{l}\text { Imja, Nepal, 2009; } \\
\text { Sakai et al. (2012) }\end{array}$ & 35.5 & 34.9 & 35.5 & 175.0 & 1.6 & -0.1 & -79.7 & 2 & 0 \\
\hline $\begin{array}{l}\text { Imja, Nepal, pre- } \\
\text { 1992; Yamada and } \\
\text { Sharma (1993), } \\
\text { Yao et al. (2012) }\end{array}$ & 61.6 & 47.7 & 49.3 & 270.2 & 29.3 & 24.9 & -77.2 & 3 & 1 \\
\hline $\begin{array}{l}\text { Imja, Nepal, 2012; } \\
\text { Somos-Valenzuela } \\
\text { et al. (2013) }\end{array}$ & 63.8 & 45.1 & 46.6 & 250.5 & 41.3 & 37.0 & -74.5 & 4 & 2 \\
\hline $\begin{array}{l}\text { Ivory, 1976; } \\
\text { Hicks et al. (1990) }\end{array}$ & 1.5 & 0.8 & 0.7 & 1.1 & 73.1 & 110.0 & 28.9 & 6 & 5 \\
\hline $\begin{array}{l}\text { Ivory, 1980; } \\
\text { Hicks et al. (1990) }\end{array}$ & 2.0 & 1.3 & 1.1 & 1.9 & 57.8 & 86.9 & 4.2 & 4 & 4 \\
\hline $\begin{array}{l}\text { Ivory, 1986; } \\
\text { Hicks et al. (1990) }\end{array}$ & 3.5 & 1.7 & 1.4 & 2.7 & 112.7 & 148.3 & 29.9 & 7 & 6 \\
\hline $\begin{array}{l}\text { Laguna Safuna } \\
\text { Alta, 2001; } \\
\text { Hubbard et } \\
\text { al. (2005) }\end{array}$ & 21.3 & 7.5 & 7.0 & 20.9 & 182.5 & 202.7 & 1.9 & 6 & 6 \\
\hline $\begin{array}{l}\text { Lake No Lake, } \\
\text { 1999; Geertseema } \\
\text { and Clague (2005) }\end{array}$ & 720.0 & 338.5 & 391.3 & 4228.1 & 112.7 & 84.0 & -83.0 & 7 & 5 \\
\hline
\end{tabular}


Table 3. Continued.

\begin{tabular}{|c|c|c|c|c|c|c|c|c|c|}
\hline $\begin{array}{l}\text { Site, survey date, } \\
\text { reference(s) }\end{array}$ & $\begin{array}{r}\text { Bathymetrically } \\
\text { derived volume } \\
\qquad\left(\times 10^{6} \mathrm{~m}^{3}\right)\end{array}$ & $\begin{array}{r}\text { Huggel } \\
\text { et al. } \\
(2002) \\
\text { volume }\end{array}$ & $\begin{array}{r}\text { Evans } \\
\text { et al. } \\
(1986) \\
\text { volume }\end{array}$ & $\begin{array}{r}\text { O'Connor } \\
\text { et al. } \\
(2001) \\
\text { volume }\end{array}$ & $\begin{array}{r}\text { Huggel } \\
\text { et al. } \\
(2002) \\
\text { error } \\
(\%)\end{array}$ & $\begin{array}{r}\text { Evans } \\
\text { et al. } \\
(1986) \\
\text { error } \\
(\%)\end{array}$ & $\begin{array}{r}\text { O'Connor } \\
\text { et al. } \\
(2001) \\
\text { error } \\
(\%)\end{array}$ & $\begin{array}{r}\text { Error score } \\
\text { based on all } \\
\text { three volume } \\
\text { estimate } \\
\text { methods }\end{array}$ & $\begin{array}{r}\text { Error score } \\
\text { based on } \\
\text { Huggel et al. } \\
(2002) \text { and } \\
\text { Evans (1986) }\end{array}$ \\
\hline $\begin{array}{l}\text { Lapa, 2001; } \\
\text { Petrakov et } \\
\text { al. (2007) }\end{array}$ & 0.2 & 0.4 & 0.3 & 0.4 & -43.9 & -28.6 & -49.3 & 3 & 2 \\
\hline $\begin{array}{l}\text { Lapa, 2006; } \\
\text { Petrakov } \\
\text { et al. (2007) }\end{array}$ & 0.1 & 0.2 & 0.2 & 0.2 & -33.4 & -12.8 & -34.8 & 2 & 1 \\
\hline $\begin{array}{l}\text { Leones, 2001; } \\
\text { Harrison et } \\
\text { al. (2008), } \\
\text { Loriaux and } \\
\text { Casassa (2013) }\end{array}$ & 2454.6 & 2338.4 & 3014.1 & 64139.4 & 5.0 & -18.6 & -96.2 & 2 & 0 \\
\hline $\begin{array}{l}\text { Llaca, 2004; } \\
\text { Emmer and } \\
\text { Vilimek (2013) }\end{array}$ & 0.3 & 0.4 & 0.3 & 0.5 & -32.9 & -15.2 & -40.9 & 2 & 1 \\
\hline $\begin{array}{l}\text { Longbasaba, 2009; } \\
\text { Yao et al. (2012) }\end{array}$ & 64.0 & 45.6 & 47.1 & 254.1 & 40.3 & 35.9 & -74.8 & 4 & 2 \\
\hline $\begin{array}{l}\text { Lower Barun, } \\
\text { Nepal, 1997; } \\
\text { ICIMOD (2001) }\end{array}$ & 28.0 & 24.2 & 24.1 & 104.9 & 15.7 & 16.1 & -73.3 & 2 & 0 \\
\hline $\begin{array}{l}\text { Lugge, Bhutan, } \\
\text { 2002; Sakai et } \\
\text { al. (2012) }\end{array}$ & 58.3 & 43.0 & 44.3 & 234.3 & 35.5 & 31.6 & -75.1 & 4 & 2 \\
\hline $\begin{array}{l}\text { Maud Lake, 1994; } \\
\text { Allen et al. (2009) }\end{array}$ & 78.0 & 50.0 & 51.9 & 288.8 & 56.0 & 50.4 & -73.0 & 6 & 4 \\
\hline $\begin{array}{l}\text { Miage, 2003; } \\
\text { Diolaiuti et } \\
\text { al. (2005) }\end{array}$ & 0.3 & 0.3 & 0.2 & 0.3 & 11.2 & 42.8 & 3.4 & 2 & 1 \\
\hline $\begin{array}{l}\text { Mt Elbrus, } \\
\text { 2000; Petrakov } \\
\text { et al. (2007) }\end{array}$ & 0.6 & 1.1 & 0.9 & 1.6 & -50.4 & -40.8 & -65.9 & 5 & 3 \\
\hline $\begin{array}{l}\text { MT Lake, 1982- } \\
\text { 1983; Blown and } \\
\text { Church (1985) }\end{array}$ & 0.5 & 0.4 & 0.3 & 0.4 & 31.6 & 67.0 & 17.8 & 3 & 3 \\
\hline $\begin{array}{l}\text { Mueller, 2002; } \\
\text { Allen et al. (2009) }\end{array}$ & 4.3 & 12.9 & 12.4 & 43.7 & -66.6 & -65.3 & -90.2 & 6 & 4 \\
\hline $\begin{array}{l}\text { Mueller, 2009; } \\
\text { Robertson et } \\
\text { al. (2012) }\end{array}$ & 20.0 & 28.3 & 28.4 & 130.2 & -29.2 & -29.6 & -84.6 & 4 & 2 \\
\hline $\begin{array}{l}\text { Nef, 1998; } \\
\text { Warren et al. (2001) }\end{array}$ & 770.7 & 351.4 & 407.0 & 4455.6 & 119.3 & 89.4 & -82.7 & 7 & 5 \\
\hline $\begin{array}{l}\text { Ngozumpa 2, } \\
\text { 2008; Sharma et } \\
\text { al. (2012) }\end{array}$ & 3.3 & 3.1 & 2.8 & 6.3 & 5.0 & 18.3 & -48.1 & 2 & 0 \\
\hline
\end{tabular}


Table 3. Continued.

\begin{tabular}{|c|c|c|c|c|c|c|c|c|c|}
\hline $\begin{array}{l}\text { Site, survey date, } \\
\text { reference(s) }\end{array}$ & $\begin{array}{r}\text { Bathymetrically } \\
\text { derived volume } \\
\qquad\left(\times 10^{6} \mathrm{~m}^{3}\right)\end{array}$ & $\begin{array}{r}\text { Huggel } \\
\text { et al. } \\
(2002) \\
\text { volume }\end{array}$ & $\begin{array}{r}\text { Evans } \\
\text { et al. } \\
(1986) \\
\text { volume }\end{array}$ & $\begin{array}{r}\text { O'Connor } \\
\text { et al. } \\
(2001) \\
\text { volume }\end{array}$ & $\begin{array}{r}\text { Huggel } \\
\text { et al. } \\
(2002) \\
\text { error } \\
(\%)\end{array}$ & $\begin{array}{r}\text { Evans } \\
\text { et al. } \\
(1986) \\
\text { error } \\
(\%)\end{array}$ & $\begin{array}{r}\text { O'Connor } \\
\text { et al. } \\
(2001) \\
\text { error } \\
(\%)\end{array}$ & $\begin{array}{r}\text { Error score } \\
\text { based on all } \\
\text { three volume } \\
\text { estimate } \\
\text { methods }\end{array}$ & $\begin{array}{r}\text { Error score } \\
\text { based on } \\
\text { Huggel et al. } \\
(2002) \text { and } \\
\text { Evans (1986) }\end{array}$ \\
\hline $\begin{array}{l}\text { Ngozumpa } 3 \text {, } \\
\text { 2008; Sharma et } \\
\text { al. (2012) }\end{array}$ & 10.6 & 10.3 & 9.8 & 32.2 & 2.5 & 7.9 & -67.1 & 2 & 0 \\
\hline $\begin{array}{l}\text { Ngozumpa } 4 \text {, } \\
\text { 2008; Sharma et } \\
\text { al. (2012) }\end{array}$ & 77.3 & 15.6 & 15.2 & 57.1 & 395.1 & 409.3 & 35.4 & 7 & 6 \\
\hline $\begin{array}{l}\text { Ngozumpa, 2009; } \\
\text { Thompson et } \\
\text { al. (2012) }\end{array}$ & 2.2 & 6.2 & 5.8 & 16.1 & -64.7 & -61.7 & -86.3 & 6 & 4 \\
\hline $\begin{array}{l}\text { Palcacocha, 2009; } \\
\text { Emmer and } \\
\text { Vilimek (2013) }\end{array}$ & 17.3 & 13.9 & 13.4 & 48.7 & 24.5 & 28.9 & -64.4 & 3 & 1 \\
\hline $\begin{array}{l}\text { Palcacocha, 2009; } \\
\text { Somos-Valenzuela } \\
\text { and } \\
\text { McKinney (2011) }\end{array}$ & 17.3 & 13.5 & 13.1 & 46.9 & 27.9 & 32.6 & -63.1 & 4 & 2 \\
\hline $\begin{array}{l}\text { Paqu Co, 1987; } \\
\text { Sakai et al. (2012) }\end{array}$ & 6.0 & 6.5 & 6.0 & 17.2 & -8.1 & -0.7 & -65.0 & 2 & 0 \\
\hline $\begin{array}{l}\text { Petrov Lake, 2003; } \\
\text { Engel et al. (2012) }\end{array}$ & 53.4 & 217.4 & 245.1 & 2268.6 & -75.4 & -78.2 & -97.6 & 6 & 4 \\
\hline $\begin{array}{l}\text { Petrov Lake, 2003; } \\
\text { Jansky et al. (2010) }\end{array}$ & 60.3 & 238.3 & 270.1 & 2581.6 & -74.7 & -77.7 & -97.7 & 6 & 4 \\
\hline $\begin{array}{l}\text { Petrov Lake, 1978; } \\
\text { Sevastianov and } \\
\text { Funtikov (1981); } \\
\text { Loriaux and } \\
\text { Cassasa (2013) }\end{array}$ & 20.0 & 68.9 & 72.8 & 452.8 & -71.0 & -72.5 & -95.6 & 6 & 4 \\
\hline $\begin{array}{l}\text { Petrov Lake, 2006; } \\
\text { Engel et al. (2012) }\end{array}$ & 59.2 & 229.3 & 259.3 & 2445.0 & -74.2 & -77.2 & -97.6 & 6 & 4 \\
\hline $\begin{array}{l}\text { Petrov Lake, 2008; } \\
\text { Engel et al. (2012) }\end{array}$ & 62.0 & 236.1 & 267.5 & 2548.7 & -73.7 & -76.8 & -97.6 & 6 & 4 \\
\hline $\begin{array}{l}\text { Petrov Lake, 2009; } \\
\text { Jansky et al. (2009) }\end{array}$ & 64.0 & 237.9 & 269.6 & 2575.0 & -73.1 & -76.3 & -97.5 & 6 & 4 \\
\hline $\begin{array}{l}\text { Quangzonk Co, } \\
\text { 1987; Sakai et } \\
\text { al. (2012) }\end{array}$ & 21.4 & 23.3 & 23.2 & 99.7 & -8.2 & -7.7 & -78.5 & 2 & 0 \\
\hline $\begin{array}{l}\text { Quitacocha, 2012; } \\
\text { Emmer and } \\
\text { Vilimek (2013) }\end{array}$ & 3.2 & 1.9 & 1.6 & 3.3 & 69.3 & 96.1 & -1.2 & 4 & 4 \\
\hline $\begin{array}{l}\text { Rajucolta, 2004; } \\
\text { Emmer and } \\
\text { Vilimek (2013) }\end{array}$ & 17.5 & 13.3 & 12.8 & 45.9 & 31.6 & 36.6 & -61.8 & 4 & 2 \\
\hline $\begin{array}{l}\text { Raphsthren, 1984; } \\
\text { Sakai et al. (2012) }\end{array}$ & 66.8 & 54.4 & 56.7 & 325.2 & 22.8 & 17.8 & -79.4 & 2 & 0 \\
\hline
\end{tabular}


Table 3. Continued.

\begin{tabular}{|c|c|c|c|c|c|c|c|c|c|}
\hline $\begin{array}{l}\text { Site, survey date, } \\
\text { reference }(s)\end{array}$ & $\begin{array}{r}\text { Bathymetrically } \\
\text { derived volume } \\
\qquad\left(\times 10^{6} \mathrm{~m}^{3}\right)\end{array}$ & $\begin{array}{r}\text { Huggel } \\
\text { et al. } \\
(2002) \\
\text { volume }\end{array}$ & $\begin{array}{r}\text { Evans } \\
\text { et al. } \\
(1986) \\
\text { volume }\end{array}$ & $\begin{array}{r}\text { O'Connor } \\
\text { et al. } \\
(2001) \\
\text { volume }\end{array}$ & $\begin{array}{r}\text { Huggel } \\
\text { et al. } \\
(2002) \\
\text { error } \\
(\%)\end{array}$ & $\begin{array}{r}\text { Evans } \\
\text { et al. } \\
(1986) \\
\text { error } \\
(\%)\end{array}$ & $\begin{array}{r}\text { O'Connor } \\
\text { et al. } \\
(2001) \\
\text { error } \\
(\%)\end{array}$ & $\begin{array}{r}\text { Error score } \\
\text { based on all } \\
\text { three volume } \\
\text { estimate } \\
\text { methods }\end{array}$ & $\begin{array}{r}\text { Error score } \\
\text { based on } \\
\text { Huggel et al. } \\
\text { (2002) and } \\
\text { Evans (1986) }\end{array}$ \\
\hline $\begin{array}{l}\text { Tam Pokhari, } \\
\text { 1992; } \\
\text { ICIMOD (2001) }\end{array}$ & 21.3 & 11.8 & 11.3 & 38.7 & 80.3 & 88.4 & -45.1 & 5 & 4 \\
\hline $\begin{array}{l}\text { Tararhua, 2008; } \\
\text { Emmer and } \\
\text { Vilimek (2013) }\end{array}$ & 4.2 & 8.0 & 7.5 & 22.7 & -47.1 & -43.5 & -81.3 & 4 & 2 \\
\hline $\begin{array}{l}\text { Tasman, 2009; } \\
\text { Robertson et } \\
\text { al. (2012) }\end{array}$ & 510.0 & 434.4 & 509.3 & 6003.9 & 17.4 & 0.1 & -91.5 & 2 & 0 \\
\hline $\begin{array}{l}\text { Thulagi/Dona, } \\
\text { 1995; Sakai et } \\
\text { al. (2012) }\end{array}$ & 31.8 & 23.3 & 23.2 & 99.7 & 36.3 & 37.1 & -68.1 & 4 & 2 \\
\hline $\begin{array}{l}\text { Thulagi/Dona, } \\
\text { 2009; Sakai et } \\
\text { al. (2012) }\end{array}$ & 35.4 & 31.5 & 31.9 & 151.8 & 12.1 & 10.9 & -76.7 & 2 & 0 \\
\hline $\begin{array}{l}\text { Tsho Rolpa, 1993; } \\
\text { Sakai et al. (2012) }\end{array}$ & 76.6 & 55.0 & 57.4 & 329.9 & 39.4 & 33.5 & -76.8 & 4 & 2 \\
\hline $\begin{array}{l}\text { Tsho Rolpa, Nepal, } \\
\text { 2009; Sakai et } \\
\text { al. (2012) }\end{array}$ & 85.9 & 63.6 & 66.9 & 404.4 & 35.2 & 28.5 & -78.7 & 4 & 2 \\
\hline $\begin{array}{l}\text { Tulsequah, 1958; } \\
\text { Marcus (1960) }\end{array}$ & 229.0 & 234.6 & 265.6 & 2525.1 & -2.4 & -13.8 & -90.9 & 2 & 0 \\
\hline
\end{tabular}

area in most situations. Table 3 reveals that the relationship of O'Connor et al. (2001) outperforms the other empirical relationships for Hooker, Imja (in 1992), Ivory, Laguna Safuna Alta, Lake No Lake, Miage, MT Lake, Ngozumpa 4, Quitacocha and Tam Pokhari. These lakes may be unusually deep for their respective surface areas, as were the lakes investigated by O'Connor et al. (2001).

\subsection{Geomorphometric controls of lake variability}

Figure 1 shows that glacial lakes can be exceptionally deep or exceptionally shallow for any given surface area. There are several reasons that may account for this depth variability. First, glaciers achieve different levels of erosion and sediment flux, meaning that the depth of erosion of glacial basins (overdeepenings) within which lakes sit, and the height of moraine dams that impound lakes, can be highly variable (e.g. Cook and Swift, 2012). Second, shallow lakes may develop on top of stagnant or stagnating ice (Yao et al., 2012), or where lake basins become progressively filled with sediment (Allen et al., 2009), meaning the evolution of such lakes can vary widely even if their starting morphology is the same. Third, the presence or absence of a lake outlet, and the eleva- tion of that outlet or notch with respect to the glacier terminus bed elevation, will have a significant control on the depth of water that is allowed to accumulate in any lake basin.

Some of the lakes with "highly unpredictable" or "unpredictable" volumes (Table 3) share common characteristics, which may prove instructive when deciding upon an appropriate empirical relationship with which to estimate the volume of different lake types. First, Mueller, Ngozumpa, Petrov and Mt Elbrus are all lakes that are either situated (partly or wholly) on top of stagnant or relict glacier ice or have large subaqueous ice bodies that protrude into the lake from the glacier terminus. At Mueller Glacier, Robertson et al. (2012) detected an exceptionally long $(510 \mathrm{~m})$ subaqueous ice ramp that covered $\sim 20 \%$ of the lake surface area beneath the water line, and Röhl (2005) suggested that the Mueller lake bed was ice-cored. At Ngozumpa Glacier, the lake is developing supraglacially from the coalescence of surface melt ponds on the debris-covered glacier surface (Benn et al., 2001; Thompson et al., 2012). Petrov lake is developing at the glacier terminus where it appears that an ice-cored medial moraine is mostly submerged beneath the lake surface, effectively splitting the lake into two sub-basins (Jansky et al., 2009, 2010; Engel et al., 2012). The southeastern lake 
of Mt Elbrus is reported by Petrakov et al. (2007) to have a bed composed of stagnant ice. ICIMOD (2001, 2011) categorised supraglacial lakes separately to moraine-dammed lakes, noting that there was a continuum between lake forms as supraglacial ponds evolved to supraglacial lakes, through to moraine-dammed lakes. We suggest that, because of the underlying ice content, supraglacial lakes are relatively shallow compared to moraine-dammed lakes, and hence existing relationships for the prediction of lake volume tend to overestimate lake volume.

The second grouping includes lakes situated within basins with complex bed topography, some of which may be related to focussing of glacial erosion. Hooker Lake had a greater than predicted volume in 1995 and 2002 but not in 2009. Comparison of glacier terminus position and bathymetric maps in Robertson et al. (2013) indicates that in 1995, the glacier terminus was retreating out of a deep basin. By 2002, the glacier had retreated to the position of a deep notch in the bed profile. At Ivory Glacier, lake volume was significantly underpredicted for 1976 and 1986, although less so for 1980. Examination of lake long profiles in Hicks et al. (1990) indicates that in 1976 and 1986, the glacier had recently retreated into a deep basin. The lake in these situations is disproportionately deep at one end and shallower toward the moraine dam, which means that the lake volume is not well predicted. Ivory Glacier in 1986 terminated in a nested overdeepening (a basin within a basin). This complex lake basin morphometry may thus yield lake volumes that are underpredicted by existing empirical relationships. Tam Pokhari, Checquiacocha, Maud Lake and arguably Ivory Lake all appear in places where glacial erosion may have been particularly intense and hence might be expected to generate particularly deep basins with lake volumes that are not well predicted by existing empirical relationships (Table 3). Tam Pokhari, Checquiacocha and Ivory Lake appear at the base of what would have been steep icefalls with greater potential for erosion and sediment transfer (cf. Cook et al., 2011). Maud Lake is located in what would have been a tributary glacier junction where erosion would have been intense as a consequence of enhanced ice flux (cf. Cook and Swift, 2012).

A third identifiable situation is represented by Hazard/Steele Lake, which formed when a glacier advanced across a valley (Collins and Clarke, 1977; Clarke, 1982). Table 3 reveals that empirical relationships underestimate its volume. We make the tentative suggestion that the morphometry of lake basins such as this, where the host valley has been shaped to some extent by fluvial and mass movement processes before glacier advance, means that their volumes are not well predicted by empirical relationships based on measurements of lakes that occupy basins of purely glacial origin. Lake No Lake may also fit within this category because it occupies a valley situated between two glaciers (Geertsema and Clague, 2005).

The remaining outliers from Table 3 are lakes with a range of site-specific characteristics that make their volumes hard to predict or represent situations where there is no clear reason for their unusual volumes. Some of these outliers are related to apparently unusual situations (compared to lakes upon which empirical relationships have been based). Specifically, Ngozumpa 4 is an ice-marginal moraine-dammed lake that is reported by Sharma et al. (2012) to have a deep crevice at its base, giving it an unusually deep bed; Laguna Safuna Alta has a complex history of lake level change, involving modification by engineering works, and a suspected increase in moraine dam permeability as a consequence of an earthquake in 1970 (Hubbard et al., 2005), although it is not clear why it should be unusually deep. Quitacocha and Gelhaipuco lakes are both moraine-dammed and their volumes are underestimated by empirical relationships. Again, it is unclear why this should be the case.

\subsection{Relationships by region}

An intriguing result from our analysis is that lakes within similar geographical areas do not necessarily have equally predictable lake volumes. A number of studies have adapted existing empirical relationships by adding data from specific regions (e.g. Loriaux and Cassassa, 2013) or by generating completely new relationships from known lake properties for specific regions in favour of adopting existing empirical relationships (e.g. Yao et al., 2012). There is some merit in this approach because, for example, the volumes of many of the Himalayan glacial lakes listed in Table 3 are consistently underpredicted by existing empirical formulae, indicating regional controls on lake volumes. Yet, the data set compiled in this study reveals a number of examples where lakes in the same region can have very different degrees of volume predictability. For example, the Hooker and Mueller lakes are only $\sim 1.8 \mathrm{~km}$ apart, yet empirical relationships underpredict the volume of Hooker lake and overpredict the volume of Mueller lake. The volume of Tasman lake, $<2 \mathrm{~km}$ to the east of Hooker lake, is well predicted by the relationships of Huggel et al. (2002) and Evans (1986) (Table 3). It should not, therefore, be assumed that empirical relationships derived for specific regions will perform any better than existing relationships derived from a range of sites. It is more likely that lake origin and context are key in determining how predictable lake volume might be and what type of empirical relationship to use to make that prediction.

\subsection{Relationships by lake type}

In order to better understand lake growth and the application of empirical relationships, we have re-plotted the data according to lake context (Fig. 3) and developed a corresponding conceptual model for each (Fig. 4). One of the striking results of our error analysis (Table 3) was that growing supraglacial lake volumes are not well predicted by existing empirical relationships. Supraglacial lake evolution has been examined in a number of studies (e.g. Kirkbride, 1993; Sakai 

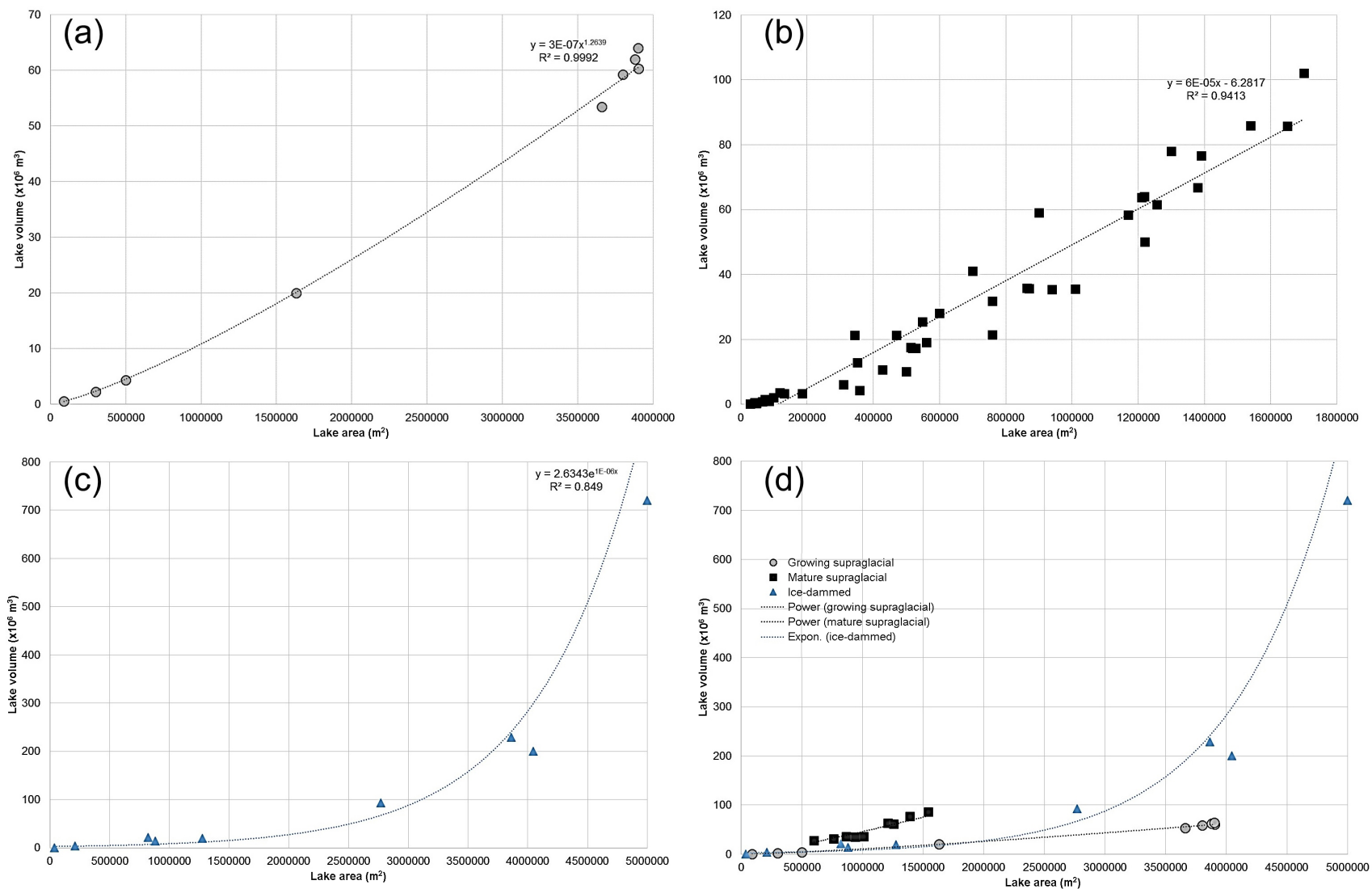

Figure 3. Plots of lake area-volume data according to different lake dynamic contexts: (a) growing supraglacial lakes; (b) moraine-dammed lakes excluding the largest lakes (Nef, Leones, Tasman) and extreme outliers (Ngozumpa 4) to facilitate comparison with the conceptual model presented in Fig. 4; (c) ice-dammed lakes; (d) growing supraglacial lakes compared to ice-dammed lakes and a selection of morainedammed lakes (labelled here as "mature supraglacial lakes"). Note that growing supraglacial lakes form a distinct population compared to other lake types.

et al., 2000, 2003, 2009; Benn et al., 2001; Thompson et al., 2012) with small ponds developing through melting of exposed ice faces and large lakes expanding primarily through calving. Sakai et al. (2009) suggested that wind-driven currents of relatively warm water were important for lake growth and calving, and hence, lake fetch (defined as the maximum lake length along the axis of glacier flow) represents a primary control on lake evolution. Their work demonstrated that supraglacial lakes expand by calving once lake fetch exceeds $\sim 80 \mathrm{~m}$ and that subaqueous thermal undercutting of ice cliffs occurred for fetches that exceed 20-30 m when the water temperature was $2-4{ }^{\circ} \mathrm{C}$. We hypothesise that, at least initially, supraglacial ponds and lakes tend to grow areally at a much faster rate than their depths do through the melting of underlying ice (Fig. 4). It is quite likely that as these lakes evolve to become moraine-dammed forms with little or no lake-bottom ice, volume will tend to increase linearly with area, as found for most moraine-dammed lakes in our compiled data set (Fig. 3b). This assertion is borne out to some extent by a plot of the limited available area-volume data for growing supraglacial lakes (equivalent data are lacking for supraglacial ponds) (Fig. 3a). These data fit a power-law function of the form $V=3 \times 10^{-7} A^{1.239}$ with an $r^{2}$ value of 0.99 , although it should be stressed that this is based on very few data points, several of which are from Petrov Lake. Figure $3 \mathrm{~d}$ shows that growing supraglacial lakes form a distinct population when compared to other data sets of icedammed lakes and a selection of moraine-dammed lakes that have evolved from supraglacial lakes (including Imja Tsho, Lower Barun, Tsho Rolpa and Thulagi). Notably, their volume increases only at a slow rate with increased area, probably because they are relatively shallow. However, Fig. 3d also illustrates that the area-volume relationship for more mature supraglacial lakes deviates significantly from that of the growing supraglacial lakes. Here, lake volume increases more rapidly, perhaps as a consequence of increased calving rate associated with deeper water as the lake-bottom ice melts out. However, it is unclear from these limited data which of these two trajectories shown on Figs. $3 d$ and 4, if either, other examples of evolving supraglacial lakes should be expected 


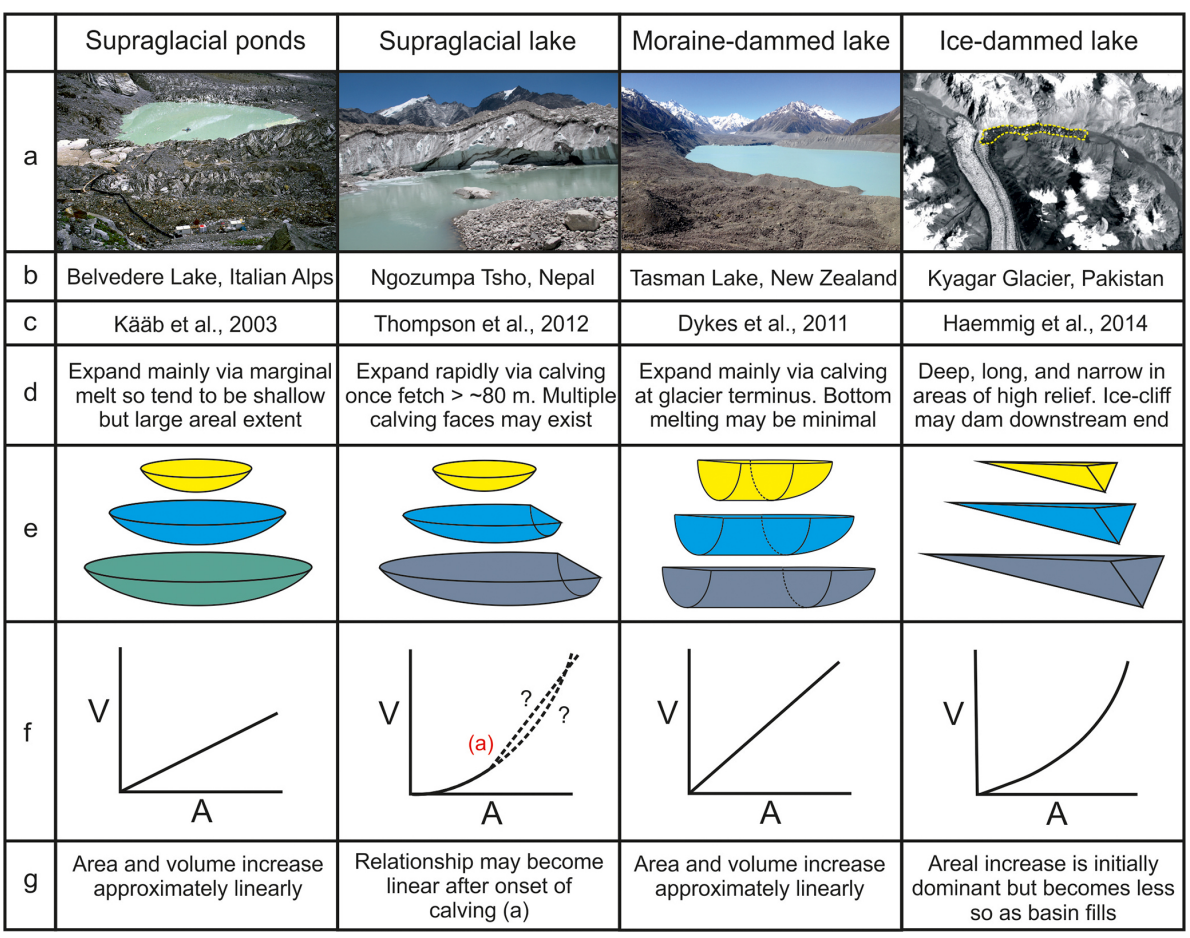

Figure 4. Conceptual consideration of glacial lake evolution and its impact on volume-area relationships: (a) imagery of typical lake types, (b) example locations, (c) associated reference for each lake type, (d) notes on evolution style and morphology, (e) idealised geometric shapes depicting evolution through time, (f) idealised area-volume relationships and (g) notes on area-volume relationships. Photograph of Belvedere Lake by Jürg Alean (http://www.swisseduc.ch/glaciers/earth_icy_planet/glaciers13-en.html?id=_16).

to follow. We suggest that it would be particularly valuable for future studies to focus on gathering empirical data on the morphometry of supraglacial lakes to help address this issue. Certainly, caution should be exercised when applying existing empirical relationships to predict the volume of growing supraglacial lakes.

In contrast, lakes that have evolved toward the morainedammed endmember appear to have more predictable volumes. Figure $3 \mathrm{~b}$ illustrates that most moraine-dammed lake volumes scale linearly with increasing area. Likewise, the available data indicate that ice-dammed lakes may evolve predictably, such that lake volume grows exponentially with increasing lake area (Figs. 3c and 4).

\section{Conclusions}

The ability to estimate accurately the volume of glacial lakes is important for the modelling of GLOF magnitudes and runout distances. Direct estimation of lake volume in the field through detailed bathymetric surveying is a potentially difficult and dangerous undertaking. Hence, many studies rely on empirically derived relationships that allow the estimation of lake volume from a measurement of lake area, which is readily gained from satellite imagery. However, there has been no systematic assessment of the performance of these existing empirical relationships or the extent to which they should apply in different glacial lake contexts. In this study, we have compiled a comprehensive data set of glacial lake area, depth and volume in order to evaluate the use of three well-known empirical relationships, namely those of Huggel et al. (2002), Evans (1986) and O'Connor et al. (2001).

Our first key finding is that lake depth and area are only moderately correlated (with an $r^{2}$ value of 0.38 ), and that for any given lake area there may be an order of magnitude difference in mean lake depth. Equally, a plot of lake area against volume revealed an $r^{2}$ value of 0.91 but with several distinct outliers in the data set. Again, for any given lake area there may be order-of-magnitude differences in lake volume. These results indicate that any relationship for predicting lake volume founded on the notion that lake area and depth should scale predictably may not always estimate lake volume reliably.

Our second key finding is that two of the three existing empirical relationships (those of Huggel et al., 2002 and Evans, 1986) give reasonable approximations of lake volume for many of the lakes examined in this study, but there are several lakes whose volumes are over- or underestimated by these relationships, sometimes with errors of as much as 50 to over $400 \%$. The relationship of O'Connor et al. (2001) is only reliable in a handful of cases, seemingly where lakes are unusually deep. 
Many of the lakes whose volumes are not well predicted by empirical relationships fall into distinct groups, meaning that it is possible to identify situations where it could be inappropriate to apply empirical relationships to estimate lake volume, important for robust assessments of GLOF risk. Specifically, these groups include (i) lakes that are developing supraglacially, which tend to grow areally by calving and edge melting, but are shallow due to the presence of ice at the lake bed or of ice ramps protruding from calving faces; (ii) lakes that occupy basins with complex bathymetries comprising multiple overdeepenings or are particularly deep due to carving by intense erosion (e.g. at the base of an icefall or at former tributary glacier junctions); and (iii) lakes that form in deglaciated valleys (e.g. when glaciers advance to block valley drainage). Other outliers represent a range of unusual cases where site-specific factors complicate the relationship between lake area and volume.

Ultimately, we develop a conceptual model of how volume should be expected to change with increasing area for a range of lake contexts, based on re-plotting of the data according to lake type. Specifically, these include moraine-dammed, icedammed, supraglacial ponds and supraglacial lakes. We suggest that further measurements of the bathymetry of growing supraglacial ponds and lakes would be very valuable in developing robust relationships for the prediction of their evolving volumes.

\section{The Supplement related to this article is available online at doi:10.5194/esurf-3-559-2015-supplement.}

Acknowledgements. We gratefully acknowledge the interactive comment from Wilfried Haeberli, which made us think critically about our use of terminology as well as about empirical lake area-volume relationships. Likewise, we thank Jürgen Herget and an anonymous reviewer for their thoughtful and constructive reviews. We are particularly grateful to Jürgen Herget for providing electronic and hard copies of an edited volume that we would not otherwise have been able to access. We thank Vladimir Konovalov for providing further reports pertinent to this study.

Edited by: J. Turowski

\section{References}

Allen, S. K., Schneider, D., and Owens, I. F.: First approaches towards modelling glacial hazards in the Mount Cook region of New Zealand's Southern Alps, Nat. Hazards Earth Syst. Sci., 9, 481-499, doi:10.5194/nhess-9-481-2009, 2009.

Benn, D. I., Wiseman, S., and Hands, K. A.: Growth and drainage of supraglacial lakes on debris-mantled Ngozumpa Glacier, Khumbu Himal, Nepal, J. Glaciol., 47, 626-638, 2001.
Blown, I. and Church, M.: Catastrophic lake drainage within the Homathko River basin, British Columbia, Can. Geotech. J., 22, 551-563, 1985.

Bolch, T., Peters, J., Yegorov, A., Pradhan, B., Buchroithner, M., and Blagoveshchensky, V.: Identification of potentially dangerous glacial lakes in the northern Tien Shan, Nat. Hazards, 59, 1691-1714, 2011.

Box, J. E. and Ski, K.: Remote sounding of Greenland supraglacial melt lakes: implications for subglacial hydraulics, J. Glaciol., 53, 257-265, 2007.

Byers, A. C., McKinney, D. C., Somos-Valenzuela, M., Watanabe, T., and Lamsal, D.: Glacial lakes of the Hinku and Hongu valleys, Makalu Barun National Park and Buffer Zone, Nepal, Nat. Hazards, 69, 115-139, 2013.

Carrivick, J. L. and Quincey, D. J.: Progressive increase in number and volume of ice-marginal lakes on the western margin of the Greenland Ice Sheet, Global Planet. Change, 116, 156-163, 2014.

Carrivick, J. L. and Tweed, F. S.: Proglacial lakes: character, behaviour and geological importance, Quaternary Sci. Rev., 78, 34$52,2013$.

Casassa, G., Wendt, J., Wendt, A., López, P., Schuler, T., Maas, H.G., Carrasco, J., and Rivera, A.: Outburst floods of glacial lakes in Patagonia: is there an increasing trend?, Geophysical Research Abstracts, Vol. 12, EGU2010-12821, 2010.

Che, T., Xiao, L., and Liou, Y.-A.: Changes in Glaciers and Glacial Lakes and the Identification of Dangerous Glacial Lakes in the Pumqu River Basin, Xizang (Tibet), Advances in Meteorology, 2014, 903709, doi:10.1155/2014/903709, 2014.

Clague, J. J. and Evans, S. G.: A review of catastrophic drainage of moraine-dammed lakes in British Columbia, Quaternary Sci. Rev., 19, 1763-1783, 2000.

Clarke, G. K.: Glacier outburst floods from "Hazard Lake", Yukon Territory, and the problem of flood magnitude prediction, J. Glaciol., 28, 3-21, 1982.

Collins, S. G. and Clarke, G. K.: History and bathymetry of a surgedammed lake, Arctic, 1977, 217-224, 1977.

Cook, S. J. and Swift, D. A.: Subglacial basins: Their origin and importance in glacial systems and landscapes, Earth-Sci. Rev., 115, 332-372, 2012.

Cook, S. J., Swift, D. A., Graham, D. J., and Midgley, N. G.: Origin and significance of 'dispersed facies' basal ice: Svinafellsjokull, Iceland, J. Glaciol., 57, 710-720, 2011.

Cunico, M.: Ice deformation associated with a glacier-dammed lake in alaska and the implications for outburst flood hydraulics, 2003, MS Thesis, Portland State University, 136 pp., 2003.

Diolaiuti, G., Kirkbride, M., Smiraglia, C., Benn, D., D'agata, C., and Nicholson, L.: Calving processes and lake evolution at Miage glacier, Mont Blanc, Italian Alps, Ann. Glaciol., 40, 207214, 2005.

Duck, R. W. and McManus, J.: Short-term bathymetric changes in an ice-contact proglacial lake, Norsk Geogr. Tidsskr., 39, 39-45, 1985.

Dykes, R. C., Brook, M. S., Robertson, C. M., and Fuller, I. C.: Twenty-First Century Calving Retreat of Tasman Glacier, Southern Alps, New Zealand, Arct. Antarct. Alp. Res., 43, 1-10, 2011.

Emmer, A. and Vilímek, V.: Review Article: Lake and breach hazard assessment for moraine-dammed lakes: an example from 
the Cordillera Blanca (Peru), Nat. Hazards Earth Syst. Sci., 13, 1551-1565, doi:10.5194/nhess-13-1551-2013, 2013.

Engel, Z., Sobr, M., and Yerokhin, S. A.: Changes of Petrov glacier and its proglacial lake in the Akshiirak massif, central Tien Shan, since 1977, J. Glaciol., 58, 388-398, 2012.

Evans, S. G.: Landslide damming in the Cordillera of Western Canada, Seattle, Washington, 111-130, 1986.

Geertsema, M. and Clague, J. J.: Jokulhlaups at Tulsequah Glacier, northwestern British columbia, Canada, Holocene, 15, 310-316, 2005.

Gilbert, R. and Desloges, J. R.: Sediments of ice-dammed, selfdraining Ape Lake, British Columbia, Can. J. Earth Sci., 24, 1735-1747, 1987.

Gruber, F. E. and Mergili, M.: Regional-scale analysis of highmountain multi-hazard and risk indicators in the Pamir (Tajikistan) with GRASS GIS, Nat. Hazards Earth Syst. Sci., 13, 2779 2796, doi:10.5194/nhess-13-2779-2013, 2013.

Haeberli, W.: Interactive comment on "Estimating the volume of Alpine glacial lakes" by Cook, S. J. and Quincey, D. J., 3, C342C343, 2015.

Haemmig, C., Huss, M., Keusen, H., Hess, J., Wegmueller, U., Ao, Z., and Kulubayi, W.: Hazard assessment of glacial lake outburst floods from Kyagar glacier, Karakoram mountains, China, Ann. Glaciol., 55, 34-44, 2014

Harrison, S., Glasser, N., Winchester, V., Haresign, E., Warren, C., Duller, G. A., Bailey, R., Ivy-Ochs, S., Jansson, K., and Kubik, P.: Glaciar León, Chilean Patagonia: Late-Holocene chronology and geomorphology, The Holocene, 18, 643-652, 2008.

Hicks, D. M., McSaveney, M. J., and Chinn, T. J. H.: Sedimentation in proglacial Ivory Lake, Southern Alps, New-Zealand, Arctic Alpine Res., 22, 26-42, 1990.

Hubbard, B., Heald, A., Reynolds, J. M., Quincey, D., Richardson, S. D., Luyo, M. Z., Portilla, N. S., and Hambrey, M. J.: Impact of a rock avalanche on a moraine-dammed proglacial lake: Laguna Safuna Alta, Cordillera Blanca, Peru, Earth Surf. Proc. Land., 30, 1251-1264, 2005.

Huggel, C., Kaab, A., Haeberli, W., Teysseire, P., and Paul, F.: Remote sensing based assessment of hazards from glacier lake outbursts: a case study in the Swiss Alps, Can. Geotech. J., 39, 316330, 2002.

Huggel, C., Haeberli, W., Kaab, A., Bieri, D., and Richardson, S.: An assessment procedure for glacial hazards in the Swiss Alps, Can. Geotech. J., 41, 1068-1083, 2004.

Jain, S. K., Lohani, A. K., Singh, R. D., Chaudhary, A., and Thakural, L. N.: Glacial lakes and glacial lake outburst flood in a Himalayan basin using remote sensing and GIS, Nat. Hazards, 62, 887-899, 2012.

Jansky, B., Engel, Z., Sobr, M., Benes, V., Spacek, K., and Yerokhin, S.: The evolution of Petrov lake and moraine dam rupture risk (Tien-Shan, Kyrgyzstan), Nat. Hazards, 50, 83-96, 2009.

Jansky, B., Sobr, M., and Engel, Z.: Outburst flood hazard: Case studies from the Tien-Shan Mountains, Kyrgyzstan, Limnologica, 40, 358-364, 2010.

Kääb, A. W. R., Haeberli, W., Huggel, C., Kargel, J. S., and Khalsa, S. J. S: Rapid ASTER imaging facilitates timely assessment of glacier hazards and disasters Eos, Transactions, American Geophysical Union, 84, 117-121, 2003.
Kirkbride, M. P.: The temporal significance of transitions from melting to calving termini at glaciers in the central Southern Alps of New Zealand, Holocene, 3, 232-240, 1993.

Loriaux, T. and Casassa, G.: Evolution of glacial lakes from the Northern Patagonia Icefield and terrestrial water storage in a sealevel rise context, Global Planet. Change, 102, 33-40, 2013.

Marcus, M. G.: Periodic Drainage of Glacier-Dammed Tulsequah Lake, British Columbia, Geogr. Rev., 50, 89-106, 1960.

Mayer, C., Lambrecht, A., Hagg, W., Helm, A., and Scharrer, K.: Post-drainage ice dam response at Lake Merzbacher, Inylchek glacier, Kyrgyzstan, Geografiska Annaler Series a-Physical Geography, 90A, 87-96, 2008.

McKillop, R. J. and Clague, J. J.: A procedure for making objective preliminary assessments of outburst flood hazard from morainedammed lakes in southwestern British Columbia, Nat. Hazards, 41, 131-157, 2007.

Mergili, M. and Schneider, J. F.: Regional-scale analysis of lake outburst hazards in the southwestern Pamir, Tajikistan, based on remote sensing and GIS, Nat. Hazards Earth Syst. Sci., 11, 1447 1462, doi:10.5194/nhess-11-1447-2011, 2011.

ICIMOD: Inventory of Glaciers, Glacial Lakes and Glacial Lake Outburst Floods: Monitoring and Early Warning Systems in the Hindu Kush-Himalayan Region, Nepal, 375 pp., 2001.

ICIMOD: Glacial Lakes and Glacial Lake Outburst Floods in Nepal, 109 pp., 2011.

O'Connor, J. E., Hardison III, J. H., and Costa, J. E.: Debris Flows from Failures of Neoglacial-Age Moraine Dams in the Three Sisters and Mount Jefferson Wilderness Areas, Oregon, 105 pp., 2001.

Petrakov, D. A., Krylenko, I. V., Chernomorets, S. S., Tutubalina, O. V., Krylenko, I. N., and Shakhmina, M. S.: Monitoring of Bashkara Glacier lakes (Central Caucasus, Russia) and modelling of their potential outburst, in: Debris flow hazard of glacial lakes in the Central Caucasus, edited by: Chen, C. L. and Major, J. J., 703-714, 2007.

Petrakov, D. A., Tutubalina, O. V., Aleinikov, A. A., Chernomorets, S. S., Evans, S. G., Kidyaeva, V. M., Krylenko, I. N., Norin, S. V., Shakhmina, M. S., and Seynova, I. B. : Monitoring of Bashkara Glacier lakes (Central Caucasus, Russia) and modelling of their potential outburst, Nat. Hazards, 61, 1293-1316, 2012.

Richardson, S. D., and Reynolds, J. M.: An overview of glacial hazards in the Himalayas, Quatern. Int., 65, 31-47, 2000.

Robertson, C. M., Benn, D. I., Brook, M. S., Fuller, I. C., and Holt, K. A.: Subaqueous calving margin morphology at Mueller, Hooker and Tasman glaciers in Aoraki/Mount Cook National Park, New Zealand, J. Glaciol., 58, 1037-1046, 2012.

Robertson, C. M., Brook, M. S., Holt, K. A., Fuller, I. C., and Benn, D. I.: Calving retreat and proglacial lake growth at Hooker Glacier, Southern Alps, New Zealand, New Zealand Geographer, 69, 14-25, 2013.

Röhl, K.: Terminus disintegration of debris-covered, lake calving glaciers, PhD Thesis, University of Otago, 2005.

Röhl, K.: Characteristics and evolution of supraglacial ponds on debris-covered Tasman Glacier, New Zealand, J. Glaciol., 54, 867-880, 2008.

Sakai, A.: Glacial Lakes in the Himalayas: A Review on Formation and Expansion Processes, Global Environmental Research, 16, 23-30, 2012. 
Sakai, A., Chikita, K., and Yamada, T.: Expansion of a morainedammed glacial lake, Tsho Rolpa, in Rolwaling Himal, Nepal Himalaya, Limnol. Oceanogr., 45, 1401-1408, 2000.

Sakai, A., Yamada, T., and Fujita, K.: Volume change of Imja glacial lake in the Nepal Himalayas, Proceedings of the International Symposium on Disaster Mitigation and Basin Wide Water Management, 7-10 December 2003, Niigata, Japan, 556-561, 2003.

Sakai, A., Nishimura, K., Kadota, T., and Takeuchi, N.: Onset of calving at supraglacial lakes on debris-covered glaciers of the Nepal Himalaya, J. Glaciol., 55, 909-917, 2009.

Sawagaki, T., Lamsal, D., Byers, A., and Watanabe, T.: Changes in surface morphology and glacial lake development of Chamlang South Glacier, eastern Nepal Himalaya, since 1964, Tokyo, Global Environ. Res., 16, 83-94, 2012.

Schneider, D. H. C., Cochachin, A., Guillén, S., and García, J.: Mapping hazards from glacier lake outburst floods based on modelling of process cascades at Lake 513, Carhuaz, Peru, Advances in Geosciences, 35, 145-155, 2014.

Sevastianov, D. V. and Funtikov A. B.: Novye dannye ob evolucii vysokogornogo ozera u konca lednika Petrova (New data on the evolution of the mountainous lake in front of the Petrov glacier), Izvestia VGO, 113, 430-435, 1981.

Sharma, C. M., Sharma, S., Bajracharya, R. M., Gurung, S., Juettner, I., Kang, S., Zhang, Q., and Li, Q.: First results on bathymetry and limnology of high-altitude lakes in the Gokyo Valley, Sagarmatha (Everest) National Park, Nepal, Limnology, 13, 181-192, 2012.

Somos-Valenzuela, M. and McKinney, D.C.: Modeling a glacial lake outburst flood (GLOF) from Palcacocha Lake, Peru. An Adaptation Partnership Workshop: Andean-Asian Mountains Global Knowledge Exchange On Glaciers, Glacial lakes, Water \& Hazard Management, Nepal, 16 pp., 2011.

Thompson, S. S., Benn, D. I., Dennis, K., and Luckman, A.: A rapidly growing moraine-dammed glacial lake on Ngozumpa Glacier, Nepal, Geomorphology, 145, 1-11, 2012.

Vincent, C., Auclair, S., and Le Meur, E.: Outburst flood hazard for glacier-dammed Lac de Rochemelon, France, J. Glaciol., 56, 91-100, 2010.

Walder, J. S. and Costa, J. E.: Outburst floods from glacier-dammed lakes: The effect of mode of lake drainage on flood magnitude, Earth Surf. Proc. Land., 21, 701-723, 1996.
Wang, X., Liu, S., Ding, Y., Guo, W., Jiang, Z., Lin, J., and Han, Y.: An approach for estimating the breach probabilities of moraine-dammed lakes in the Chinese Himalayas using remotesensing data, Nat. Hazards Earth Syst. Sci., 12, 3109-3122, doi:10.5194/nhess-12-3109-2012, 2012.

Warren, C. R. and Kirkbride, M. P.: Temperature and bathymetry of ice-contact lakes in Mount Cook National Park, New Zealand, New Zeal. J. Geol. Geop., 41, 133-143, 1998.

Warren, C., Benn, D., Winchester, V., and Harrison, S.: Buoyancydriven lacustrine calving, Glaciar Nef, Chilean Patagonia, J. Glaciol., 47, 135-146, 2001.

Westoby, M. J., Glasser, N. F., Brasington, J., Hambrey, M. J., Quincey, D. J., and Reynolds, J. M.: Modelling outburst floods from moraine-dammed glacial lakes, Earth-Sci. Rev., 134, 137159, 2014.

Wilcox, A. C., Wade, A. A., and Evans, E. G.: Glacial Outburst Flooding, Bear Glacier, Kenai Fjords National Park, Alaska, 41 pp., 2013.

Yamada, T. and Sharma, C.: Glacier lakes and outburst floods in the Nepal Himalaya, IAHS Publications-Publications of the International Association of Hydrological Sciences, 218, 319-330, 1993.

Yao, X., Liu, S., Sun, M., Wei, J., and Guo, W.: Volume calculation and analysis of the changes in moraine-dammed lakes in the north Himalaya: a case study of Longbasaba lake, J. Glaciol., 58, 753-760, 2012.

Zemp, M., Frey, H., Gärtner-Roer, I., Nussbaumer, S. U., Hoelzle, M., Paul, F., Haeberli, W., Denzinger, F., Ahlstroem, A. P., Anderson, B., Bajracharya, S., Baroni, C., Braun, L. N., Caceres, B. E., Casassa, G., Cobos, G., Davila, L. R., Delgado Granados, H., Demuth, M. N., Espizua, L., Fischer, A., Fujita, K., Gadek, B., Ghazanfar, A., Hagen, J. O., Holmlund, P., Karimi, N., Li, Z., Pelto, M., Pitte, P., Popovnin, V. V., Portocarrero, C. A., Prinz, R., Sangewar, C. V., Severskiy, I., Sigurdsson, O., Soruco, A., Usubaliev, R., and Vincent, C.: Historically unprecedented global glacier decline in the early 21 st century, J. Glaciol., 61, 745-762, 2015. 